\title{
Agreement on Provisional Arrangements \\ in Afghanistan Pending the Re-establishment of \\ Permanent Government I nstitutions
}

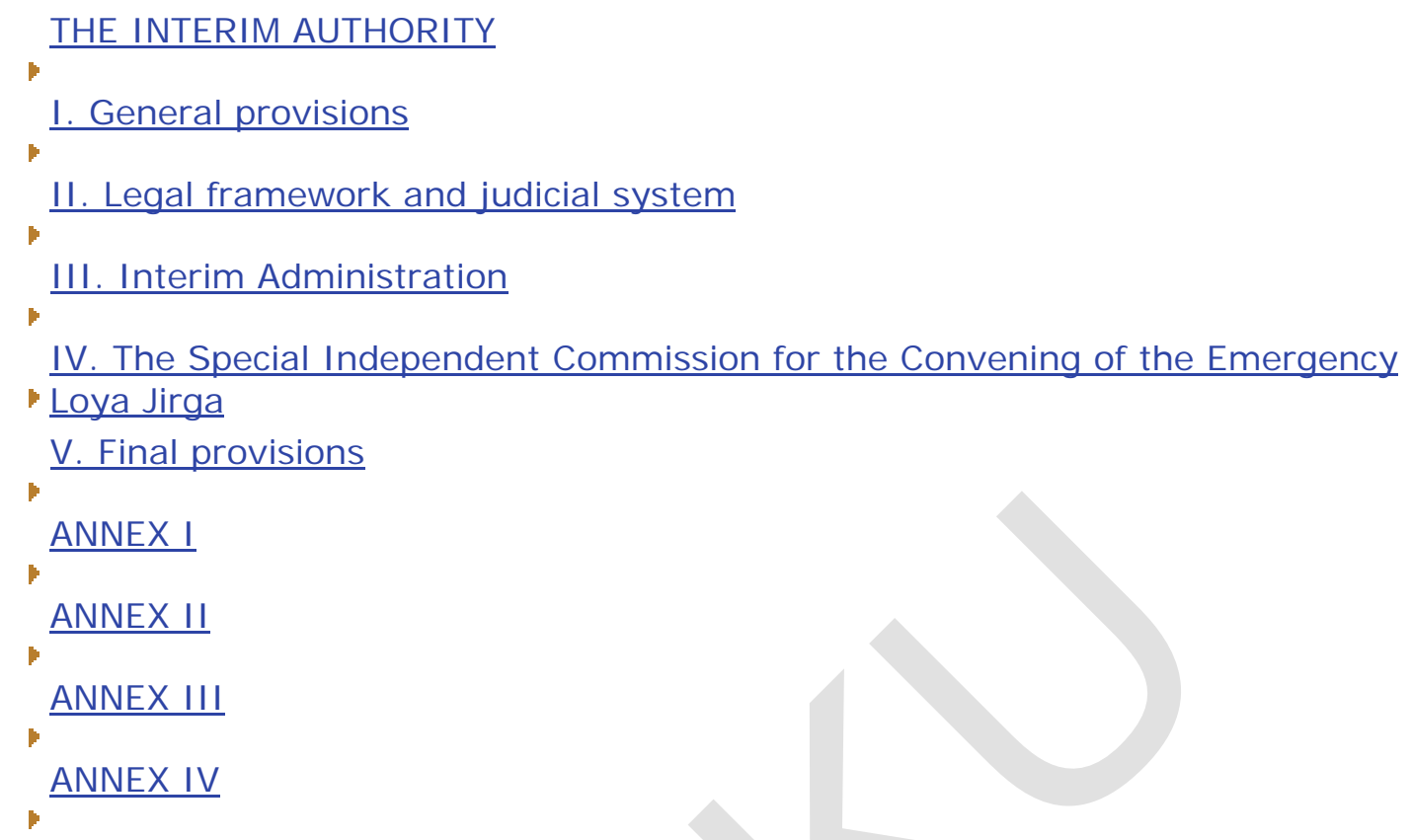

The participants in the UN Talks on Afghanistan,

In the presence of the Special Representative of the Secretary-General for Afghanistan,

Determined to end the tragic conflict in Afghanistan and promote national reconciliation, lasting peace, stability and respect for human rights in the country,

Reaffirming the independence, national sovereignty and territorial integrity of Afghanistan,

Acknowledging the right of the people of Afghanistan to freely determine their own political future in accordance with the principles of Islam, democracy, pluralism and social justice,

Expressing their appreciation to the Afghan mujahidin who, over the years, have defended the independence, territorial integrity and national unity of the country and have played a major role in the struggle against terrorism and oppression, and whose sacrifice has now made them both heroes of jihad and champions of peace, stability and reconstruction of their beloved homeland, Afghanistan,

Aware that the unstable situation in Afghanistan requires the implementation of emergency interim arrangements and expressing their deep appreciation to His Excellency Professor Burhanuddin Rabbani for his readiness to transfer power to an interim authority which is to be established pursuant to this agreement, 
Recognizing the need to ensure broad representation in these interim arrangements of all segments of the Afghan population, including groups that have not been adequately represented at the UN Talks on Afghanistan,

Noting that these interim arrangements are intended as a first step toward the establishment of a broad-based, gender-sensitive, multi-ethnic and fully representative government, and are not intended to remain in place beyond the specified period of time,

Recognizing that some time may be required for a new Afghan security force to be fully constituted and functional and that therefore other security provisions detailed in Annex I to this agreement must meanwhile be put in place,

Considering that the United Nations, as the internationally recognized impartial institution, has a particularly important role to play, detailed in Annex II to this agreement, in the period prior to the establishment of permanent institutions in Afghanistan,

Have agreed as follows:

THE INTERIM AUTHORITY

I. General provisions

1) An Interim Authority shall be established upon the official transfer of power on 22 December 2001.

2) The Interim Authority shall consist of an Interim Administration presided over by a Chairman, a Special Independent Commission for the Convening of the Emergency Loya J irga, and a Supreme Court of Afghanistan, as well as such other courts as may be established by the Interim Administration. The composition, functions and governing procedures for the Interim Administration and the Special Independent Commission are set forth in this agreement.

3) Upon the official transfer of power, the Interim Authority shall be the repository of Afghan sovereignty, with immediate effect. As such, it shall, throughout the interim period, represent Afghanistan in its external relations and shall occupy the seat of Afghanistan at the United Nations and in its specialized agencies, as well as in other international institutions and conferences.

4) An Emergency Loya Jirga shall be convened within six months of the establishment of the Interim Authority. The Emergency Loya J irga will be opened by His Majesty Mohammed Zaher, the former King of Afghanistan. The Emergency Loya J irga shall decide on a Transitional Authority, including a broad-based transitional administration, to lead Afghanistan until such time as a fully representative government can be elected through free and fair elections to be held no later than two years from the date of the convening of the Emergency Loya Jirga.

5) The Interim Authority shall cease to exist once the Transitional Authority has been established by the Emergency Loya Jirga. 
6) A Constitutional Loya Jirga shall be convened within eighteen months of the establishment of the Transitional Authority, in order to adopt a new constitution for Afghanistan. In order to assist the Constitutional Loya Jirga prepare the proposed Constitution, the Transitional Administration shall, within two months of its commencement and with the assistance of the United Nations, establish a Constitutional Commission.

\section{Legal framework and judicial system}

1) The following legal framework shall be applicable on an interim basis until the adoption of the new Constitution referred to above:

i) The Constitution of 1964, a/ to the extent that its provisions are not inconsistent with those contained in this agreement, and b/ with the exception of those provisions relating to the monarchy and to the executive and legislative bodies provided in the Constitution; and ii) existing laws and regulations, to the extent that they are not inconsistent with this agreement or with international legal obligations to which Afghanistan is a party, or with those applicable provisions contained in the Constitution of 1964, provided that the Interim Authority shall have the power to repeal or amend those laws and regulations.

2) The judicial power of Afghanistan shall be independent and shall be vested in a Supreme Court of Afghanistan, and such other courts as may be established by the Interim Administration. The Interim Administration shall establish, with the assistance of the United Nations, a Judicial Commission to rebuild the domestic justice system in accordance with I slamic principles, international standards, the rule of law and Afghan legal traditions.

III. Interim Administration

A. Composition

1) The Interim Administration shall be composed of a Chairman, five Vice Chairmen and 24 other members. Each member, except the Chairman, may head a department of the Interim Administration.

2) The participants in the UN Talks on Afghanistan have invited His Majesty Mohammed Zaher, the former King of Afghanistan, to chair the Interim Administration. His Majesty has indicated that he would prefer that a suitable candidate acceptable to the participants be selected as the Chair of the Interim Administration.

3) The Chairman, the Vice Chairmen and other members of the Interim Administration have been selected by the participants in the UN Talks on Afghanistan, as listed in Annex IV to this agreement. The selection has been made on the basis of professional competence and personal integrity from lists submitted by the participants in the UN Talks, with due regard to the ethnic, geographic and religious composition of Afghanistan and to the importance of the participation of women.

4) No person serving as a member of the Interim Administration may simultaneously hold membership of the Special Independent Commission for the Convening of the Emergency Loya J irga. 


\section{B. Procedures}

1) The Chairman of the Interim Administration, or in his/her absence one of the Vice Chairmen, shall call and chair meetings and propose the agenda for these meetings.

2) The Interim Administration shall endeavour to reach its decisions by consensus. In order for any decision to be taken, at least 22 members must be in attendance. If a vote becomes necessary, decisions shall be taken by a majority of the members present and voting, unless otherwise stipulated in this agreement. The Chairman shall cast the deciding vote in the event that the members are divided equally. C. Functions

1) The Interim Administration shall be entrusted with the day-to-day conduct of the affairs of state, and shall have the right to issue decrees for the peace, order and good government of Afghanistan.

2) The Chairman of the Interim Administration or, in his/her absence, one of the Vice Chairmen, shall represent the Interim Administration as appropriate.

3) Those members responsible for the administration of individual departments shall also be responsible for implementing the policies of the Interim Administration within their areas of responsibility.

4) Upon the official transfer of power, the Interim Administration shall have full jurisdiction over the printing and delivery of the national currency and special drawing rights from international financial institutions. The Interim Administration shall establish, with the assistance of the United Nations, a Central Bank of Afghanistan that will regulate the money supply of the country through transparent and accountable procedures.

5) The Interim Administration shall establish, with the assistance of the United Nations, an independent Civil Service Commission to provide the Interim Authority and the future Transitional Authority with shortlists of candidates for key posts in the administrative departments, as well as those of governors and uluswals, in order to ensure their competence and integrity.

6) The Interim Administration shall, with the assistance of the United Nations, establish an independent Human Rights Commission, whose responsibilities will include human rights monitoring, investigation of violations of human rights, and development of domestic human rights institutions. The Interim Administration may, with the assistance of the United Nations, also establish any other commissions to review matters not covered in this agreement.

7) The members of the Interim Administration shall abide by a Code of Conduct elaborated in accordance with international standards.

8) Failure by a member of the Interim Administration to abide by the provisions of the Code of Conduct shall lead to his/her suspension from that body. The decision to suspend a member shall be taken by a two-thirds majority of the membership of the Interim Administration on the proposal of its Chairman or any of its Vice Chairmen. 9) The functions and powers of members of the Interim Administration will be further elaborated, as appropriate, with the assistance of the United Nations.

\section{The Special Independent Commission for the Convening of the Emergency Loya} Jirga

1) The Special Independent Commission for the Convening of the Emergency Loya J irga shall be established within one month of the establishment of the Interim Authority. The Special Independent Commission will consist of twenty-one members, a number of whom should have expertise in constitutional or customary law. The members will be selected from lists of candidates submitted by participants in the UN Talks on Afghanistan as well as Afghan professional and civil society groups. The United Nations will assist with the establishment and functioning of the commission and of a substantial secretariat. 
2) The Special Independent Commission will have the final authority for determining the procedures for and the number of people who will participate in the Emergency Loya J irga. The Special Independent Commission will draft rules and procedures specifying (i) criteria for allocation of seats to the settled and nomadic population residing in the country; (ii) criteria for allocation of seats to the Afghan refugees living in Iran, Pakistan, and elsewhere, and Afghans from the diaspora; (iii) criteria for inclusion of civil society organizations and prominent individuals, including Islamic scholars, intellectuals, and traders, both within the country and in the diaspora. The Special Independent Commission will ensure that due attention is paid to the representation in the Emergency Loya Jirga of a significant number of women as well as all other segments of the Afghan population.

3) The Special Independent Commission will publish and disseminate the rules and procedures for the convening of the Emergency Loya Jirga at least ten weeks before the Emergency Loya Jirga convenes, together with the date for its commencement and its suggested location and duration.

4) The Special Independent Commission will adopt and implement procedures for monitoring the process of nomination of individuals to the Emergency Loya Jirga to ensure that the process of indirect election or selection is transparent and fair. To pre-empt conflict over nominations, the Special Independent Commission will specify mechanisms for filing of grievances and rules for arbitration of disputes.

5) The Emergency Loya Jirga will elect a Head of the State for the Transitional Administration and will approve proposals for the structure and key personnel of the Transitional Administration.

V. Final provisions

1) Upon the official transfer of power, all mujahidin, Afghan armed forces and armed groups in the country shall come under the command and control of the Interim Authority, and be reorganized according to the requirements of the new Afghan security and armed forces.

2) The Interim Authority and the Emergency Loya Jirga shall act in accordance with basic principles and provisions contained in international instruments on human rights and international humanitarian law to which Afghanistan is a party.

3) The Interim Authority shall cooperate with the international community in the fight against terrorism, drugs and organized crime. It shall commit itself to respect international law and maintain peaceful and friendly relations with neighbouring countries and the rest of the international community.

4) The Interim Authority and the Special Independent Commission for the Convening of the Emergency Loya J irga will ensure the participation of women as well as the equitable representation of all ethnic and religious communities in the Interim Administration and the Emergency Loya J irga.

5) All actions taken by the Interim Authority shall be consistent with Security Council resolution 1378 ( 14 November 2001) and other relevant Security Council resolutions relating to Afghanistan.

6) Rules of procedure for the organs established under the Interim Authority will be elaborated as appropriate with the assistance of the United Nations.

This agreement, of which the annexes constitute an integral part, done in Bonn on this 5th day of December 2001 in the English language, shall be the authentic text, in a single copy which shall remain deposited in the archives of the United Nations. Official texts shall be provided in Dari and Pashto, and such other languages as the Special Representative of the Secretary-General may designate. The Special Representative of the Secretary-General shall send certified copies in English, Dari and Pashto to each of the participants. 


\section{For the participants in the UN Talks on Afghanistan:}

Ms. Amena Afzali

Mr. S. Hussain Anwari

Mr. Hedayat Amin Arsala

Mr. Sayed Hamed Gailani

Mr. Rahmatullah Musa Ghazi

Eng. Abdul Hakim

Mr. Houmayoun J areer

Mr. Abbas Karimi

Mr. Mustafa Kazimi

Dr. Azizullah Ludin

Mr. Ahmad Wali Massoud

Mr. Hafizullah Asif Mohseni

Prof. Mohammad I shaq Nadiri

Mr. Mohammad Natiqi

Mr. Yunus Qanooni

Dr. Zalmai Rassoul

Mr. H. Mirwais Sadeq

Dr. Mohammad J alil Shams

Prof. Abdul Sattar Sirat

Mr. Humayun Tandar

Mrs. Sema Wali

General Abdul Rahim Wardak

Mr. Pacha Khan Zadran

Witnessed for the United Nations by:

Mr. Lakhdar Brahimi

Special Representative of the Secretary-General for Afghanistan

\section{ANNEX I}

INTERNATIONAL SECURITY FORCE

1. The participants in the UN Talks on Afghanistan recognize that the responsibility for providing security and law and order throughout the country resides with the Afghans themselves. To this end, they pledge their commitment to do all within their means and influence to ensure such security, including for all United Nations and other personnel of international governmental and non-governmental organizations deployed in Afghanistan.

2. With this objective in mind, the participants request the assistance of the international community in helping the new Afghan authorities in the establishment and training of new Afghan security and armed forces.

3. Conscious that some time may be required for the new Afghan security and armed forces to be fully constituted and functioning, the participants in the UN Talks on Afghanistan request the United Nations Security Council to consider authorizing the early deployment to Afghanistan of a United Nations mandated force. This force will assist in the maintenance of security for Kabul and its surrounding areas. Such a force could, as appropriate, be progressively expanded to other urban centres and other areas.

4. The participants in the UN Talks on Afghanistan pledge to withdraw all military units from Kabul and other urban centers or other areas in which the UN mandated force is deployed. It would also be desirable if such a force were to assist in the rehabilitation of Afghanistan's infrastructure. 


\section{$* * *$ \\ ANNEX II \\ ROLE OF THE UNITED NATIONS DURING THE INTERIM PERIOD}

1. The Special Representative of the Secretary-General will be responsible for all aspects of the United Nations' work in Afghanistan.

2. The Special Representative shall monitor and assist in the implementation of all aspects of this agreement.

3. The United Nations shall advise the Interim Authority in establishing a politically neutral environment conducive to the holding of the Emergency Loya Jirga in free and fair conditions. The United Nations shall pay special attention to the conduct of those bodies and administrative departments which could directly influence the convening and outcome of the Emergency Loya Jirga.

4. The Special Representative of the Secretary-General or his/her delegate may be invited to attend the meetings of the Interim Administration and the Special Independent Commission on the Convening of the Emergency Loya J irga.

5. If for whatever reason the Interim Administration or the Special Independent Commission were actively prevented from meeting or unable to reach a decision on a matter related to the convening of the Emergency Loya Jirga, the Special Representative of the Secretary-General shall, taking into account the views expressed in the Interim Administration or in the Special Independent Commission, use his/her good offices with a view to facilitating a resolution to the impasse or a decision.

6. The United Nations shall have the right to investigate human rights violations and, where necessary, recommend corrective action. It will also be responsible for the development and implementation of a programme of human rights education to promote respect for and understanding of human rights.

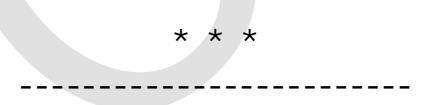

ANNEX III

REQUEST TO THE UNITED NATIONS BY THE PARTICIPANTS

AT THE UN TALKS ON AFGHANISTAN

The participants in the UN Talks on Afghanistan hereby

1. Request that the United Nations and the international community take the necessary measures to guarantee the national sovereignty, territorial integrity and unity of Afghanistan as well as the non-interference by foreign countries in Afghanistan's internal affairs;

2. Urge the United Nations, the international community, particularly donor countries and multilateral institutions, to reaffirm, strengthen and implement their commitment to assist with the rehabilitation, recovery and reconstruction of Afghanistan, in coordination with the Interim Authority;

3. Request the United Nations to conduct as soon as possible (i) a registration of voters in advance of the general elections that will be held upon the adoption of the new constitution by the constitutional Loya Jirga and (ii) a census of the population of Afghanistan.

4. Urge the United Nations and the international community, in recognition of the heroic role played by the mujahidin in protecting the independence of Afghanistan and the dignity of its people, to take the necessary measures, in coordination with the Interim Authority, to assist in the reintegration of the mujahidin into the new Afghan security and armed forces; 
5. Invite the United Nations and the international community to create a fund to assist the families and other dependents of martyrs and victims of the war, as well as the war disabled;

6. Strongly urge that the United Nations, the international community and regional organizations cooperate with the Interim Authority to combat international terrorism, cultivation and trafficking of illicit drugs and provide Afghan farmers with financial, material and technical resources for alternative crop production.

\section{$* * *$ \\ ANNEX IV \\ COMPOSITION OF THE INTERIM ADMINISTRATION}

Chairman: Hamid Karzai

\section{Vice Chairmen:}

Vice-Chair \& Women's Affairs: Dr. Sema Samar Vice-Chair \& Defence: Muhammad Qassem Fahim Vice-Chair \& Planning: Haji Muhammad Mohaqqeq Vice-Chair \& Water and Electricity: Shaker Kargar Vice-Chair \& Finance: Hedayat Amin Arsala

\section{Members:}

Department of Foreign Affairs: Dr. Abdullah Abdullah

Department of the Interior: Muhammad Yunus Qanooni

Department of Commerce: Seyyed Mustafa Kazemi

Department of Mines \& Industries: Muhammad Alem Razm

Department of Small Industries: Aref Noorzai

Department of Information \& Culture: Dr. Raheen Makhdoom

Department of Communication: Ing. Abdul Rahim

Department of Labour \& Social Affairs: Mir Wais Sadeq

Department of Hajj \& Auqaf: Mohammad Hanif Hanif Balkhi

Department of Martyrs \& Disabled: Abdullah Wardak

Department of Education: Abdul Rassoul Amin

Department of Higher Education: Dr. Sharif Faez

Department of Public Health: Dr. Suhaila Seddiqi

Department of Public Works: Abdul Khaliq Fazal

Department of Rural Development: Abdul Malik Anwar

Department of Urban Development: Haji Abdul Qadir

Department of Reconstruction: Amin Farhang

Department of Transport: Sultan Hamid Sultan

Department for the Return of Refugees: Enayatullah Nazeri

Department of Agriculture: Seyyed Hussein Anwari

Department of Irrigation: Haji Mangal Hussein

Department of Justice: Abdul Rahim Karimi

Department of Air Transport \& Tourism: Abdul Rahman

Department of Border Affairs: Amanullah Zadran 